\title{
REAL-TIME, IN SITU MEASUREMENTS OF ATMOSPHERIC OPTICAL ABSORPTION IN THE VISIBLE VIA PHOTOACOUSTIC SPECTROSCOPY -IV. VISIBILITY DEGRADATION AND AEROSOL OPTICAL PROPERTIES IN LOS ANGELES*
}

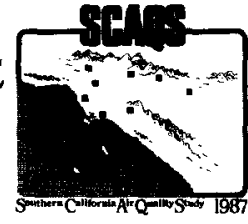

K. M. Adams, L. I. Davis, JR. and S. M. Japar

Research Staff, Ford Motor Company, Dearborn, MI 48121-2053, U.S.A.

and

\author{
D. R. FINLEY \\ Department of Atmospheric, Oceanic and Space Research, University of Michigan, Ann Arbor, MI 48109- \\ 2143, U.S.A
}

(First received 10 April 1989 and in final form 25 July 1989)

\begin{abstract}
Aerosol light absorption $\left(b_{a b s}\right)$ has been measured in real-time in Los Angeles with a validated photoacoustic technique, and its impact on visibility degradation has been examined. These measurements were collected during ten days in the summer of 1987 for the Southern California Air Quality Study (SCAQS). Aerosol $b_{\text {abs }}(\lambda=514.5 \mathrm{~nm})$ varied from an hourly average value of $7 \times 10^{-6} \mathrm{~m}^{-1}$ in the 3-4 and 4-5 a.m. periods of 13 July to $9 \times 10^{-5} \mathrm{~m}^{-1}$ in the 7-8 a.m. period of both 28 August and 3 September. This $b_{\text {nbs, }}$ which is due solely to elemental carbon (EC), showed a distinct diurnal pattern with low values at night, increasing around sunrise to higher values through mid-afternoon. Comparison of these data with aerosol light scattering data clearly illustrates that the contribution of aerosol light absorption to visibility degradation increases in importance under less polluted conditions. Other urban and rural studies show similar results.
\end{abstract}

Key word index: Atmospheric carbon, black carbon, elemental carbon, particulate carbon, photoacoustic spectrophone, atmospheric optics, visibility, light absorption, optical absorption.

\section{INTRODUCTION}

A number of studies have tried to link visibility degradation in both urban (Groblicki et al., 1981; Wolff et al., 1981, 1982; Dzubay et al., 1982; Pratsinis et al., 1984) and rural areas (Japar et al., 1986) to gas and aerosol components in the atmosphere. All of these studies suffer from the fact that there has not been a generally agreed upon method for the measurement of the light absorption ( $\left.b_{\mathrm{abs}}\right)$ by aerosols. Atmospheric aerosol light absorption has been shown to be due solely to EC (Rosen et al., 1978; Yasa et al., 1979; Japar et al., 1986; Adams et al., 1990), and can contribute significantly to visibility degradation.

Atmospheric aerosol $b_{\text {abs }}$ data in the literature result either from one of the varieties of the integrating plate technique (Lin et al., 1973), or from the difference between light scattering measured at a point by nephelometry and total light extinction measured over

* The third paper in this series is "Measurement of atmospheric elemental carbon: Real-time data for Los Angeles during Summer 1987". (Adams et al., 1990.) Atmospheric Environment (in press). $\mathrm{km}$ pathlengths by a telephotometer (Dzubay et al., 1982; Lewis and Dzubay, 1986). Both of these approaches have drawbacks. In the case of the integrating plate approach, samples are collected on various filter media and the difference in light attenuation by the filter before and after sample collection is attributed to light absorption by the collected aerosol. Unfortunately, it is difficult to calibrate this technique, and the optical properties of the collected aerosol may be perturbed by filter-sample or sample-sample interactions. In the case of the telephotometer approach, calculation of aerosol light absorption requires the precise measurement of the optical properties of all the other components of the atmosphere so that accurate subtraction from the telephotometer total light extinction measurement can be carried out. The mathematical book-keeping in this case is complex because (1) the optical measurements required generally have not been made at the same wavelength, thereby creating the need to correct for differences in response due to wavelength, and (2) there is no guarantee that the point measurements of light scattering, for example, are representative of the integrated telephotometer measurement taken over a pathlength of more than $1 \mathrm{~km}$. 
The recent development and validation of a photoacoustic technique for the in situ measurement of optical absorption in the atmosphere (Adams, 1988; Adams et al., 1989a,b) overcomes these objections. It is capable of making continuous light absorption measurement on ambient air drawn through a cell, and it can be calibrated using a gas with a known absorption coefficient. This instrumentation was deployed in the Los Angeles area during the Southern California Air Quality Study (SCAQS) in the summer of 1987, and the results of that study are the basis of this report.

\section{EXPERIMENTAL}

Sampling took place in a parking lot on the Claremont McKenna College campus in Claremont, CA, on 10 days: 19 , 24 June, 13-15 July, 27-29 August and 2-3 September 1987; the first few hours of 25 June have been included. The site is in the center of the Los Angeles basin and at the southwest base of the San Gabriel Mountains. Data were collected continuously. The sampling periods were from 1 to 5 a.m., 6 to 10 a.m., 11 a.m. to 5 p.m., and from 6 p.m. to midnight PDT

\section{(A) Measurement of aerosol light absorption}

The photoacoustic spectrometer and procedure for aerosol light absorption measurements have been described in detail previously (Adams, 1988; Adams et al., 1989, 1990), and are only briefly discussed here. The light source was an Ar ion laser $(\lambda=514.5 \mathrm{~nm})$ whose $1 \mathrm{~W}$ beam was modulated at the resonance frequency of the photoacoustic cell. Ambient air was drawn into this cell through a $\mathrm{MnO}_{2}$ denuder (Adams et al., 1986) which effectively removes atmospheric $\mathrm{NO}_{2}$ gas, while aerosol matter passes through unaffected. The instrument was calibrated for optical absorption using a standard $\mathrm{NO}_{2}$ /air mixture; $\mathrm{NO}_{2}$ has an absorption coefficient of $0.316 \mathrm{~m}^{2} \mathrm{~g}^{-1}$ at $514.5 \mathrm{~nm}$ (Terhune and Anderson, 1977). This instrument was housed in an air conditioned $8 \mathrm{ft}$ $\times 12 \mathrm{ft}$ trailer, and the denuder tube extended through the wall of the trailer, about $30 \mathrm{~cm}$ from the outside wall and $2 \mathrm{~m}$ above the ground.

\section{(B) Measurement of aerosol light scattering}

Aerosol light scattering was measured by integrating nephelometry (MRI, Model No. 1568), using a broad-band light source centered on $500 \mathrm{~nm}$. The instrument was calibrated using Fluorocarbon 12 as a standard, and zero was set using clean air. The calibration was checked about every 24 h. Although the inlet was not heated, no effort was made to keep the air sample at ambient temperature during the analysis. The nephelometer was also housed in the air conditioned trailer, and air samples were introduced into the instrument through $3 \mathrm{in} .(7.6 \mathrm{~cm})$ o.d. tubing. The air was sampled about $1 \mathrm{~m}$ from the inlet to the photoacoustic cell.

\section{RESULTS AND DISCUSSION}

\section{(A) Atmospheric optics} by

The attenuation of light in the atmosphere is defined

$$
b_{\mathrm{ext}}=b_{\mathrm{abs}}^{\mathrm{g}}+b_{\mathrm{scat}}^{\mathrm{z}}+b_{\mathrm{abs}}^{\mathrm{a}}+b_{\mathrm{scat}}^{\mathrm{a}}
$$

where $b_{\text {exi }}$ represents total light extinction; $b_{\mathrm{abs}}^{\mathrm{g}}$ and $b_{\text {scat }}^{\mathrm{g}}$ represent light absorption and light scattering, respectively, by gases in the atmosphere; and $b_{\text {abs }}^{\text {and }}$ and $b_{\text {scat }}^{\mathbf{a}}$ represent light absorption and light scattering, respectively, by aerosols in the atmosphere. The gaseous contributions to light extinction in the visible region are generally small in urban areas (Groblicki $e t$ al., 1981; Dzubay et al., 1982; Pratsinis et al., 1984). The $b_{\text {scat }}^{g}$ is essentially equal to the Rayleigh scattering due to molecular oxygen and nitrogen. The $b_{\mathrm{abs}}^{\mathrm{g}}$ in the visible region is limited to $\mathrm{NO}_{2}$, and this can be calculated if the $\mathrm{NO}_{2}$ concentration is known. On the other hand, the aerosol optical properties are highly variable. The $b_{\mathrm{abs}}^{\mathrm{a}}$ in the visible is due only to $\mathrm{EC}$ (Rosen et al., 1978; Yasa et al., 1979; Japar et al., 1986; Adams et al., 1990), however $b_{\text {scal }}^{\text {a }}$ is produced by a wide range of aerosol compositions. Aerosols are usually the major contributors to visible light extinction in urban atmospheres.

\section{(B) Hourly-averaged results}

Hourly-averaged aerosol $b_{\text {abs }}$ and $b_{\text {scat }}$ measured during the 10 study days are in Tables 1 and 2 . The aerosol $b_{\text {abs }}$ varied from $0.07 \times 10^{-4} \mathrm{~m}^{-1}$ in the $3-4$ and 4-5 a.m. periods of 13 July to a high of 0.91 $\times 10^{-4} \mathrm{~m}^{-1}$ in the 7-8 a.m. period of both 28 August and 3 September, while aerosol $b_{\text {scat }}$ varied from a minimum value of $0.38 \times 10^{-4} \mathrm{~m}^{-1}$ in the 4-5 a.m. period of 2 September to a maximum of 7.80 $\times 10^{-4} \mathrm{~m}^{-1}$ during the 11 a.m. -12 noon period of 29 August. The sum of these two optical parameters is the total light extinction, $b_{\text {ext }}$, due to aerosols. Over the course of the experiment, hourly-averaged $b_{\mathrm{ext}}$ varied from $0.53 \times 10^{-4} \mathrm{~m}^{-1}$ during 2-3 p.m. on 2 September to $8.26 \times 10^{-4} \mathrm{~m}^{-1}$ from 11 a.m. -12 noon on 29 August.

There is a clear diurnal variability in the aerosol $b_{\text {abs }}$, with low values at night rising to maximum values in the mid-morning which are maintained through late afternoon. This general pattern can be seen in the ten day averaged-hourly data presented in Table 3. The behavior is understandable when one considers that EC is essentially responsible for aerosol light absorption (Rosen et al., 1978; Yasa et al., 1979; Japar et al., 1986; Adams et al., 1990). Elemental carbon aerosol is a primary emission from combustion sources dominated in the Los Angeles basin by motor vehicles (Pratsinis et al., 1984, 1988). Thus, the early morning increase to peak values in mid-morning corresponds to the onset of the morning rush hour. Certain days show bimodal peaks in $b_{\text {abs }}$, e.g. 28 August shows a peak at 7 a.m. and then a larger one at 1 p.m.

The diurnal pattern of aerosol $b_{\text {scal }}$ is similar to that for aerosol $b_{\text {abs }}$ except that the peak values are achieved about 3-h later, around noon. This can be seen in Table 3. It reflects the fact that light scattering is dominated by secondary aerosols formed photochemically in the atmosphere (White and Roberts, 1977).

The contribution of aerosol light absorption to the total aerosol light extinction is defined as the ratio $b_{\text {abs }} / b_{\text {ext }}$. Hourly-averaged values varied from 0.04 during 1-4 a.m. on 15 July to 0.39 during 8-9 a.m. on 2 September. The 10 day averaged-hourly data in Table 
Table 1. Hourly-averaged aerosol light absorption $\left(10^{-5} \mathrm{~m}^{-1}\right)$

\begin{tabular}{|c|c|c|c|c|c|c|c|c|c|c|c|}
\hline $\begin{array}{l}\text { Starting } \\
\text { hour }\end{array}$ & $6 / 19$ & $6 / 24$ & $6 / 25$ & $7 / 13$ & $\begin{array}{l}\text { Date } \\
7 / 14\end{array}$ & $7 / 15$ & $8 / 27$ & $8 / 28$ & $8 / 29$ & $9 / 02$ & $9 / 03$ \\
\hline 0 & & & & & & & 2.4 & & & 2.2 & \\
\hline 1 & 2.0 & 2.0 & 2.1 & 1.1 & 2.4 & 1.3 & 2.2 & 2.7 & 3.0 & 1.2 & 2.4 \\
\hline 2 & 2.4 & 1.7 & 2.5 & 1.0 & 2.2 & 1.4 & 2.3 & 2.7 & 3.5 & 1.8 & 2.5 \\
\hline 3 & 2.9 & 1.6 & 2.3 & 0.7 & 2.0 & 1.5 & 2.3 & 3.2 & 3.5 & 1.1 & 2.6 \\
\hline 4 & 2.7 & 1.9 & 2.7 & 0.7 & 1.8 & 1.6 & 2.5 & 3.4 & 4.2 & 2.0 & 2.6 \\
\hline \multicolumn{12}{|l|}{5} \\
\hline 6 & 3.5 & 2.1 & & 6.2 & 2.2 & 1.6 & 6.6 & 6.7 & 4.4 & 4.0 & 7.4 \\
\hline 7 & 3.1 & 2.8 & & 4.7 & 3.0 & 2.1 & 7.1 & 9.1 & 5.1 & 4.9 & 9.1 \\
\hline 8 & 5.1 & 3.1 & & 4.9 & 3.8 & 1.8 & 5.3 & 5.7 & 4.1 & 5.3 & 4.2 \\
\hline 9 & 5.1 & 3.6 & & 6.7 & 3.8 & 2.2 & 6.9 & 4.1 & 3.4 & 1.9 & 8.3 \\
\hline \multicolumn{12}{|l|}{10} \\
\hline 11 & 3.0 & 4.3 & & 4.3 & 3.5 & 2.9 & 7.2 & 5.8 & 4.6 & & 6.6 \\
\hline 12 & 3.1 & 5.3 & & 2.9 & 3.1 & 2.9 & 6.8 & 5.7 & 4.3 & 3.9 & 4.6 \\
\hline 13 & 3.1 & 5.3 & & 4.7 & 3.5 & 3.1 & 5.4 & 8.2 & 4.2 & 1.0 & 4.6 \\
\hline 14 & 2.6 & 5.7 & & 4.5 & 4.9 & 3.6 & 7.9 & 8.0 & 4.3 & 1.0 & 3.0 \\
\hline 15 & 2.2 & 5.9 & & 4.4 & 6.2 & 3.2 & 7.9 & & 3.8 & 3.0 & 2.7 \\
\hline 16 & 2.6 & 6.0 & & 3.7 & 5.7 & 3.0 & 6.8 & 7.0 & 4.3 & 4.2 & 2.6 \\
\hline \multicolumn{12}{|l|}{17} \\
\hline 18 & 2.2 & 3.3 & & 2.3 & 3.3 & 3.1 & 3.5 & 4.3 & 2.7 & 3.6 & \\
\hline 19 & 1.6 & 1.9 & & 2.1 & 2.7 & 2.6 & 2.8 & 3.7 & 2.9 & 3.9 & 1.9 \\
\hline 20 & 1.9 & 1.6 & & 1.8 & 2.0 & 1.8 & 2.2 & 2.1 & 2.4 & 4.3 & 1.6 \\
\hline 21 & 2.7 & 1.8 & & 1.8 & 1.0 & 1.6 & 2.6 & 2.1 & 2.0 & 4.1 & 1.9 \\
\hline 22 & 1.9 & 1.5 & & 1.9 & 1.1 & 1.9 & 2.7 & 2.3 & 2.3 & 4.0 & 1.2 \\
\hline 23 & 1.6 & 1.9 & & 1.7 & 1.0 & 1.8 & 2.9 & 2.5 & 2.3 & 3.6 & 1.2 \\
\hline
\end{tabular}

Table 2. Hourly-averaged aerosol light scattering $\left(10^{-4} \mathrm{~m}^{-1}\right)$

\begin{tabular}{|c|c|c|c|c|c|c|c|c|c|c|c|}
\hline $\begin{array}{l}\text { Starting } \\
\text { hour }\end{array}$ & $6 / 19$ & $6 / 24$ & $6 / 25$ & $7 / 13$ & $7 / 14$ & $\begin{array}{l}\text { Date } \\
7 / 15\end{array}$ & $8 / 27$ & $8 / 28$ & $8 / 29$ & $9 / 02$ & $9 / 03$ \\
\hline 0 & & & & & & & 2.32 & & & 0.55 & \\
\hline 1 & 1.29 & 2.69 & 3.56 & 1.20 & 1.08 & 3.43 & 2.40 & 2.52 & 3.37 & 0.55 & 1.38 \\
\hline 2 & 1.50 & 2.69 & 3.51 & 1.20 & 1.17 & 3.43 & 2.57 & 2.52 & 3.41 & 0.73 & 1.38 \\
\hline 3 & 1.83 & 3.01 & 3.26 & 1.15 & 1.24 & 3.50 & 2.78 & 2.78 & 4.67 & 0.44 & 1.48 \\
\hline 4 & 1.79 & 3.18 & 3.35 & 1.06 & 1.27 & 3.15 & 3.03 & 3.25 & 5.17 & 0.38 & 1.99 \\
\hline \multicolumn{12}{|l|}{5} \\
\hline 6 & 1.73 & 3.03 & & 1.71 & 1.48 & 3.73 & 4.26 & 3.56 & 4.96 & 1.79 & 2.66 \\
\hline 7 & 2.11 & 3.84 & & 2.56 & 2.14 & 4.43 & 4.72 & 4.41 & 4.79 & 0.83 & 2.93 \\
\hline 8 & 3.38 & 5.12 & & 4.01 & 3.71 & 4.76 & 4.33 & 4.41 & 5.40 & 0.83 & 3.21 \\
\hline \multirow{2}{*}{\multicolumn{12}{|c|}{$\begin{array}{r}9 \\
10\end{array}$}} \\
\hline & & & & & & & & & & & \\
\hline 11 & 2.92 & 5.82 & & 2.68 & 3.34 & 4.20 & 5.01 & 4.31 & 7.80 & & 3.93 \\
\hline 12 & 2.06 & 6.03 & & 1.88 & 3.57 & 4.04 & 4.04 & 4.24 & 7.36 & 1.68 & 3.03 \\
\hline 13 & 2.34 & 6.37 & & 2.83 & 3.64 & 4.53 & 3.17 & 5.44 & 7.12 & 0.45 & 3.23 \\
\hline 14 & 2.06 & 6.32 & & 2.86 & 3.96 & 4.53 & 4.24 & 5.21 & 6.76 & 0.43 & 2.43 \\
\hline 15 & 1.93 & 6.02 & & 3.12 & 4.51 & 4.32 & 3.75 & & 6.46 & 1.57 & 2.31 \\
\hline 16 & 2.16 & 5.27 & & 2.93 & 4.37 & 3.71 & 3.80 & 4.99 & 5.84 & 2.33 & 2.38 \\
\hline \multicolumn{12}{|l|}{17} \\
\hline 18 & 1.80 & 3.06 & & 1.15 & 2.21 & 3.26 & 2.66 & 3.27 & 4.63 & 1.35 & \\
\hline 19 & 1.10 & 2.59 & & 0.99 & 1.57 & 2.51 & 1.57 & 3.08 & 4.67 & 1.45 & 1.38 \\
\hline 20 & 1.32 & 2.24 & & 0.93 & 1.81 & 2.00 & 1.69 & 2.78 & 3.83 & 1.53 & 1.50 \\
\hline 21 & 1.66 & 2.36 & & 1.03 & 1.78 & 1.74 & 1.74 & 2.74 & 4.55 & 1.25 & 1.40 \\
\hline 22 & 1.52 & 2.84 & & 1.06 & 2.18 & 2.00 & 2.11 & 2.78 & 4.16 & 1.05 & 1.70 \\
\hline 23 & 1.57 & 3.18 & & 0.99 & 2.34 & 2.75 & 2.30 & 2.78 & 3.92 & 1.18 & 1.90 \\
\hline
\end{tabular}

3 show that the aerosol $b_{\mathrm{abs}} / b_{\text {ext }}$ generally peaks at 6-8 a.m., decreases through midday and then peaks again around 7 p.m. This variability can be explained by the facts that (1) light absorption is dominated by EC in the primary vehicle emissions which will be elevated during the morning and evening rush hours; and (2) light scattering, which is dominated by photochemically formed aerosols, will generally be minimal both in the morning before the onset of much photochemistry and again in the early evening when the photochemical cloud moves east in the Los Angeles basin.

\section{(C) Daily-averaged results}

The variability in the overall 10 day averages for the optical parameters at the bottom of Table 4 suggests 
Table 3. Ten day average hourly aerosol optical parameters

\begin{tabular}{llll}
\hline $\begin{array}{l}\text { Starting } \\
\text { hour }\end{array}$ & $\begin{array}{c}b_{\text {abs }} \\
\left(10^{-5} \mathrm{~m}^{-1}\right)\end{array}$ & $\begin{array}{c}b_{\text {scat }} \\
\left(10^{-4} \mathrm{~m}^{-1}\right)\end{array}$ & $b_{\text {abs }} / b_{\text {ext }}$ \\
\hline 1 & $2.0 \pm 0.6^{*}$ & $1.99 \pm 0.96^{*}$ & $0.10 \pm 0.05^{*}$ \\
2 & $2.2 \pm 0.6$ & $2.06 \pm 0.93$ & $0.11 \pm 0.05$ \\
3 & $2.1 \pm 0.9$ & $2.29 \pm 1.22$ & $0.10 \pm 0.05$ \\
4 & $2.4 \pm 0.9$ & $2.43 \pm 1.33$ & $0.11 \pm 0.08$ \\
5 & & & \\
6 & $4.5 \pm 2.0$ & $2.89 \pm 1.15$ & $0.13 \pm 0.08$ \\
7 & $5.1 \pm 2.4$ & $3.28 \pm 1.29$ & $0.15 \pm 0.09$ \\
8 & $4.3 \pm 1.1$ & $3.92 \pm 1.23$ & $0.12 \pm 0.09$ \\
9 & $4.6 \pm 2.0$ & $4.50 \pm 1.62$ & $0.09 \pm 0.07$ \\
10 & & & \\
11 & $4.7 \pm 1.5$ & $4.45 \pm 1.50$ & $0.09 \pm 0.03$ \\
12 & $4.2 \pm 1.3$ & $3.79 \pm 1.73$ & $0.11 \pm 0.04$ \\
13 & $4.3 \pm 1.8$ & $3.91 \pm 1.89$ & $0.11 \pm 0.04$ \\
14 & $4.5 \pm 2.1$ & $3.88 \pm 1.87$ & $0.12 \pm 0.04$ \\
15 & $4.4 \pm 1.8$ & $3.78 \pm 1.63$ & $0.11 \pm 0.03$ \\
16 & $4.6 \pm 1.6$ & $3.78 \pm 1.25$ & $0.11 \pm 0.03$ \\
17 & & & \\
18 & $3.1 \pm 0.6$ & $2.60 \pm 1.04$ & $0.12 \pm 0.04$ \\
19 & $2.6 \pm 0.7$ & $2.09 \pm 1.08$ & $0.13 \pm 0.04$ \\
20 & $2.2 \pm 0.8$ & $1.96 \pm 0.79$ & $0.11 \pm 0.05$ \\
21 & $2.2 \pm 0.8$ & $2.03 \pm 0.97$ & $0.11 \pm 0.06$ \\
22 & $2.1 \pm 0.8$ & $2.14 \pm 0.89$ & $0.10 \pm 0.07$ \\
23 & $2.1 \pm 0.8$ & $2.29 \pm 0.87$ & $0.10 \pm 0.05$ \\
\hline
\end{tabular}

*The uncertainties are standard deviations.

that aerosol light absorption, and elemental carbon, have a greater impact on visibility degradation when there is less pollution in the Los Angeles basin. Aerosol light absorption remained fairly constant around an average value of $0.34( \pm 0.07) \times 10^{-4} \mathrm{~m}^{-1}$, while $b_{\text {scat }}$ and $b_{\text {ext }}$ varied more widely, with their average values being $3.0( \pm 1.2) \times 10^{-4} \mathrm{~m}^{-1}$ and 3.3 $( \pm 1.2) \times 10^{-4} \mathrm{~m}^{-1}$, respectively (see Table 4). The
Table 4. Daily average aerosol optical parameters

\begin{tabular}{lccccc}
\hline Date & $\begin{array}{c}b_{\text {abs }} \\
\left(10^{-4} \mathrm{~m}^{-1}\right)\end{array}$ & $\begin{array}{c}b_{\text {ext }} \\
\end{array}$ & $b_{\text {abs }} / b_{\text {ext }}$ & $\begin{array}{c}\text { Elemental } \\
\text { carbon } \\
\left(\mu \mathrm{g} \mathrm{m}^{-3}\right)\end{array}$ \\
\hline $6 / 19 / 87$ & 0.27 & 1.98 & 2.25 & 0.12 & 2.74 \\
$6 / 24 / 87$ & 0.32 & 4.06 & 4.38 & 0.07 & 3.15 \\
$7 / 13 / 87$ & 0.30 & 1.98 & 2.28 & 0.13 & 3.01 \\
$7 / 14 / 87$ & 0.30 & 2.56 & 2.86 & 0.10 & 2.97 \\
$7 / 15 / 87$ & 0.22 & 3.56 & 3.78 & 0.06 & 2.24 \\
$8 / 27 / 87$ & 0.46 & 3.23 & 3.69 & 0.12 & 4.61 \\
$8 / 28 / 87$ & 0.47 & 3.64 & 4.11 & 0.11 & 4.67 \\
$8 / 29 / 87$ & 0.36 & 5.26 & 5.62 & 0.06 & 3.55 \\
$9 / 02 / 87$ & 0.30 & 1.04 & 1.34 & 0.22 & 3.04 \\
$9 / 03 / 87$ & 0.36 & 2.37 & 2.73 & 0.13 & 3.62 \\
Average & 0.34 & 2.97 & 3.30 & 0.11 & 3.36 \\
Std. dev. & 0.07 & 1.16 & 1.19 & 0.04 & 0.74 \\
\hline
\end{tabular}

average aerosol $b_{\mathrm{abs}} / b_{\mathrm{ext}}$ varied only from 0.06 on both 15 July and 29 August to 0.22 on 2 September, with its daily average value equal to $0.11( \pm 0.04)$.

This impact of $b_{\mathrm{abs}}$ and EC on visibility is further illustrated in Fig. 1, where hourly-averaged aerosol optical parameters are presented for two different days, 29 August and 2 September. For these two days the average EC levels were essentially the same, $3.6 \mu \mathrm{g} \mathrm{m}^{-3}$ and $3.0 \mu \mathrm{g} \mathrm{m}^{-3}$, respectively, as was the average aerosol $b_{\text {abs }}, 0.36 \times 10^{-4} \mathrm{~m}^{-1}$ and 0.30 $\times 10^{-4} \mathrm{~m}^{-1}$, respectively. On 29 August, the average aerosol $b_{\text {ext }}=5.6 \times 10^{-4} \mathrm{~m}^{-1}$ corresponds to an average visibility due to aerosols of only $7 \mathrm{~km}$ (using the Koschmieder relationship, $L_{\mathrm{v}}=3.92 / b_{\text {ext }}$ ). On 2 September, the air was much cleaner, with aerosol $b_{\text {ext }}$ $=1.3 \times 10^{-4} \mathrm{~m}^{-1}$ and $L_{\mathrm{v}}=30 \mathrm{~km}$. The impact of aerosol $b_{\mathrm{abs}}$, and $\mathrm{EC}$, is apparent when aerosol $b_{\mathrm{abs}} / b_{\mathrm{ext}}$
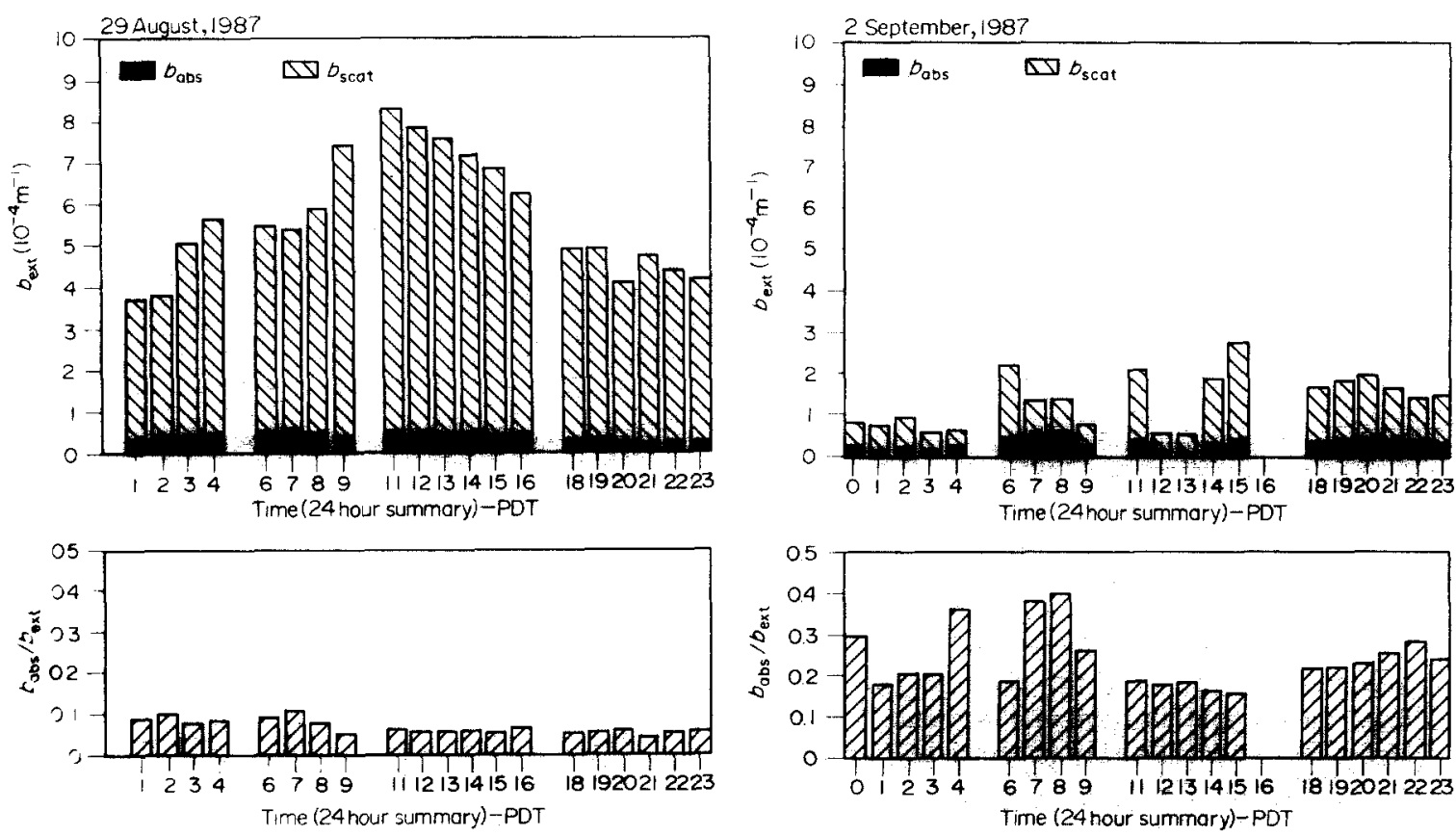

Fig. 1. Aerosol optical parameters for 2 days in Los Angeles. 
for the 2 days is compared. On 29 August aerosol light absorption was responsible, on average, for only $6 \%$ of the visibility degradation caused by aerosols, while on the relatively clean 2 September aerosol light absorption accounted for about $22 \%$ of the aerosolrelated visibility degradation.

\section{(D) Comparison with previous results}

The average daily aerosol $b_{\mathrm{abs}} / b_{\mathrm{ext}}$ for the $10 \mathrm{sam}$ pling days in Los Angeles is $0.11 \pm 0.04$, a value similiar to most data for other urban areas, when one considers the limitations of previous $b_{\mathrm{abs}}$ data. For the cities of Lennox and Duarte, in the Los Angeles basin, one can calculate aerosol $b_{\mathrm{abs}} / b_{\mathrm{ext}}$ values of 0.16 and 0.23 , respectively, for data from 23 October 1980 (Pratsinis et al., 1984); in Detroit, Michigan, during the period of 15-21 July 1981 (Wolf et al., 1982), the calculated average value is 0.09 ; and in Houston, Texas, during the period of 11-19 September 1980 (Dzubay et al., 1982), the calculated average value is 0.14. Only in Denver during wintertime 'Brown Cloud' episodes, have significantly higher values been calculated. During November-December 1978 (Groblicki et al., 1981), using the integrating plate technique to measure light absorption, the calculated average aerosol $b_{\mathrm{abs}} / b_{\mathrm{ext}}$ is 0.31 , while another data set using the telephotometer approach during January 1982 (Lewis and Dzubay, 1986) gives a calculated average value of only 0.11 . Keep in mind that, with the possible exception of the telephotometer-based analysis, these values should be considered as upper limits to the real aerosol $b_{\mathrm{abs}} / b_{\mathrm{ext}}$ because of the probable overestimation of the aerosol light absorption by the integrating plate technique.

Perhaps the most interesting comparison is between rural and urban data which both clearly illustrate that the aerosol light absorption contribution to visibility degradation increases under less polluted conditions. The rural data were collected at Allegheny Mountain in southwestern Pennsylvania in August 1983 (Japar et al., 1986). Aerosol light extinction by aerosols was amazingly similiar in the urban and rural locations. For Allegheny Mountain the average aerosol light extinction was about $1.9 \times 10^{-4} \mathrm{~m}^{-1}$, while in Los Angeles (Table 4) it was $3.3 \times 10^{-4} \mathrm{~m}^{-1}$. While the clean periods tended to be much cleaner at Allegheny Mountain than in Los Angeles, the maximum aerosol light extinctions reported were similiar. At Allegheny Mountain $b_{\text {ex }}^{\text {p }}$ ranged from about $2 \times 10^{-5} \mathrm{~m}^{-1}$ to 5.5 $\times 10^{-4} \mathrm{~m}^{-1}$, while in Los Angeles the range was $1.3-5.6 \times 10^{-4} \mathrm{~m}^{-1}$. Average aerosol light absorption was a relatively small fraction of the total aerosol light extinction, 0.13 at Allegheny Mountain and 0.11 in Los Angeles. (The Allegheny Mountain data are also an upper limit which should be lowered by about $40 \%$ to approach the true value (Japar et al., 1986).) During the clean periods at both sites, aerosol $b_{\mathrm{abs}} / b_{\mathrm{ext}}$ increased significantly with the value reaching 0.37 at Allegheny Mountain when the aerosol $b_{\text {scat }}$ was 1.6

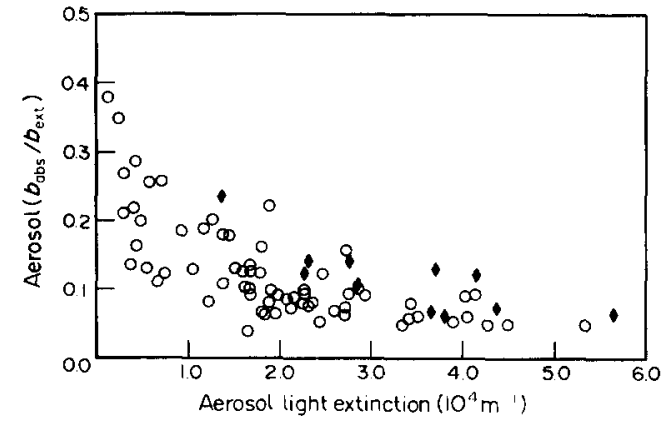

Fig. 2. The contribution of aerosol light absorption to total light extinction at Allegheny Mountain and in Los Angeles: $O, 4-6 \mathrm{~h}$-averaged data from Allegheny Mountain in August, 1983; $\bullet$, daily-averaged data from Los Angeles in the summer of 1987.

$\times 10^{-5} \mathrm{~m}^{-1}$. This relationship between aerosol $b_{\mathrm{abs}} /$ $b_{\text {ext }}$ and aerosol total light extinction is shown in Fig. 2 for both sites. (Daily average Los Angeles data are used in order to minimize the impact of the difference in the diurnal patterns for primary and secondary pollutants in near-to-source regions.) A closer look at the available data indicates that this relationship in Fig. 2 is due to the relative invariability of aerosol light absorption as compared to aerosol light scattering. This should be expected since aerosol light absorption is controlled by EC, a primary pollutant whose concentration is much less subject to variabilities in light intensity, temperature, winds, etc., than are the major light scattering components, aerosol $\mathrm{SO}_{4}^{2-}$ and secondary organic aerosols.

\section{CONCLUSIONS}

Photoacoustic spectroscopy has been used to measure aerosol light absorption in Los Angeles during the summer of 1987. This approach has the advantage over other techniques of being able to directly measure light absorption using a reliable calibration method, and the validity of this approach has been demonstrated (Adams et al., 1989, 1990).

Aerosol light absorption and aerosol light scattering in Los Angeles, determined over 10 sampling days during the summer of 1987, show distinct and different diurnal patterns. Light absorption tends to peak in the early morning and maintain high levels throughout the day, and then sharply decrease in the early evening to minimum levels throughout the night. A second peak is possible in the late afternoon. Light scattering tends to peak in the late morning, decrease slowly throughout the rest of the day to minimum values around midnight.

The urban and rural data show that the contribution of aerosol light absorption to the total aerosol light extinction increases in importance during relatively clean periods. This occurs because aerosol light absorption is due almost entirely to the primary 
pollutant $\mathrm{EC}$ which does not change much on a daily basis. On the other hand, aerosol light scattering, the dominant contributor to total light extinction, is caused principally by inorganic and organic aerosols which are formed photochemically, such that the magnitude of aerosol light scattering is much more dependent on meteorological conditions.

Acknowledgements - The authors would like to thank Drs R H. Hammerle, J. M. Norbeck, W. R. Pierson and M. Shelef for their support throughout the course of this project. Ms $S$. J. Rudy was extremely helpful in the workup of the final validated data set. Appreciation should also be noted for the support of the SCAQS coordinators, including the Coordinating Research Council, and in particular for Dr S. V. Hering, presently with Sonoma Technology, and Dr D. R. Lawson of the California Air Resources Board.

\section{REFERENCES}

Adams K. M. (1988) Real-time in situ measurements of atmospheric optical absorption in the visible via photoacoustic spectroscopy I. Evaluation of photoacoustic cells. Appl. Opt. 27, 4052-4056.

Adams K. M., Davis L. I. Jr., Japar S. M., Finley D. R. and Cary R. A. (1990) Measurement of atmospheric elemental carbon: Real-time data for Los Angeles during Summer 1987. Atmospheric Environment 597-604.

Adams K. M., Davis L. I., Jr., Japar S. M. and Pierson W. R. (1989) Real-time in situ measurements of atmospheric optical absorption in the visible via photoacoustic spectroscopy II. Validation for atmospheric elemental carbon aerosol. Atmospheric Environment 23, 693-700.

Adams K. M., Japar S. M. and Pierson W. R. (1986) Development of a $\mathrm{MnO}_{2}$-coated, cylindrical denuder for removing $\mathrm{NO}_{2}$ from atmospheric samples. Atmospheric Environment 20, 1211-1215.

Cass G. R. (1979) On the relationship between sulfate air quality and visibility with examples in Los Angeles. At mospheric Environment 13, 1069-1084.

Cass G. R., Boone R. M. and Macias E. C. (1982) Emissions and air quality relationships for atmospheric carbon particles in Los Angeles. In Particulate Carbon: Atmospheric Life Cycle (edited by Wolff G. T. and Klimish R. L.), pp. 207-240. Plenum Publishing, New York.

Cass G. R., Conklin M. H., Shah J. J., Huntzicker J. J. and Macias E. C. (1984) Elemental carbon concentrations: estimation of a historical data base. Atmospheric Environment 18, 153-162.

Dzubay T. G. and Clubb K. W. (1981) Comparison of telephotometer measurements of extinction coefficients with scattering and absorption coefficients. Atmospheric Environment 15, 2617-2624.

Dzubay T. G., Stevens R. K., Lewis C. W., Hern D. H., Courtney W. J., Tesch J. W. and Mason M. A. (1982)
Visibility and aerosol composition in Houston, Texas. Envir. Sci. Technol. 16, 514-525.

Groblicki P. J., Wolff G. T. and Countess R. J. (1981) Visibility-reducing species in the Denver 'Brown Cloud'I. Relationships between extinction and chemical composition. Atmospheric Environment 15, 2473-2484.

Japar S. M., Szkarlat A. C. and Pierson W. R. (1984) The determination of the optical properties of airborne particle emissions from diesel vehicles. Sci. Total Envir. 36, $121-130$

Japar S. M., Brachaczek W. W., Gorse R. A., Jr., Norbeck J. M. and Pierson W. R. (1986) The contribution of elemental carbon to the optical properties of rural atmospheric aerosols. Atmospheric Environment 20, 1281-1289.

Lewis C. W. and Dzubay T. G. (1986) Measurement of light absorption extinction in Denver. Aerosol Sci. Technol. 5 , 325-336.

Lin C.-I., Baker M. B. and Charlson R. J. (1973) Absorption coefficient of atmospheric aerosols: a method for measurement. Appl. Opt. 12, 1356-1363.

Macias E. S. and Hopke P. K. (1981) Wintertime carbonaceous aerosols in Los Angeles: An exploration of the role of elemental carbon. Amer. Chem. Soc. Symp. Ser. 167, 235-250.

Pratsinis S., Novakov T., Ellis E. C. and Friedlander S. K. (1984) The carbon containing component of the Los Angeles Aerosol: source apportionment and contributions to the visibility budget. J. Air Pollut. Control Ass. 34, 643-650.

Pratsinis S. E., Zeldin M. D. and Ellis E. C. (1988) Source resolution of the fine carbonaceous aerosol by principal component-stepwise regression analysis. Envir. Sci. Technol. 22, 212-216.

Rosen H., Hansen A. D. A., Gundel L. and Novakov T. (1978) Identification of the optically absorbing component in urban aerosols. Appl. Opt. 17, 3859-3861.

Szkarlat A. C. and Japar S. M. (1981) Light absorption by airborne aerosols: comparison of integrating plate and spectrophone techniques. Appl. Opt. 20, 1151-1155.

Terhune R. W. and Anderson J. E. (1977) Spectrophone measurements of the absorption of visible light by aerosols in the atmosphere: Opt. Lett. 1, 70-72.

White W. H. and Roberts P. T. (1977) On the nature and origins of visibility-reducing aerosols in the Los Angeles air basin. Atmospheric Environment 11, 803-812.

Wolff G. T., Countess R. J., Groblicki P. J., Ferman M. A Cadle S. H. and Mulbaier J. L. (1981) Visibility-reducing species in the Denver 'Brown Cloud'-II. Sources and temporal patterns. Atmospheric Environment 15, 24852502.

Wolff G. T., Ferman M. A., Kelly N. A., Stroup D. P. and Ruthkosky M. S. (1982) The relationships between the chemical composition of fine particles and visibility in the Detroit metropolitan area. J. Air Pollut. Control Ass. 32, 1216-1220.

Yasa Z., Amer N. M., Rosen H., Hansen A. D. A. and Novakov T. (1979) Photoacoustic investigation of urban aerosol particles. Appl. Opt. 18, 2528-2530. 